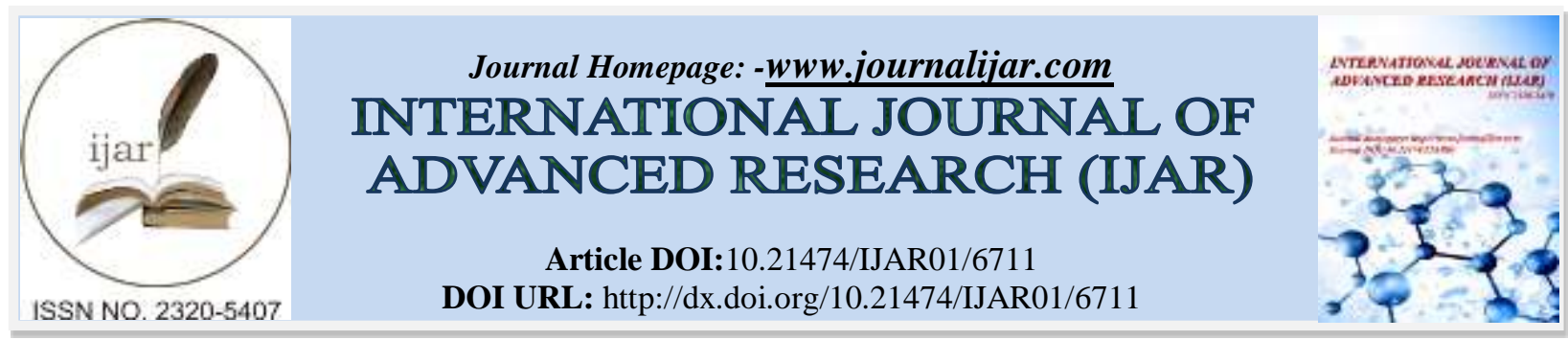

RESEARCH ARTICLE

\title{
EPIDEMIOLOGICAL REPORT ON OUTBREAK INVESTIGATION OF AES/JE IN MUZAFFARPUR DISTRICT, BIHAR IN 2016.
}

\author{
Dr. Ragini Mishra ${ }^{1}$ and Dr. Navin Mishra ${ }^{2}$. \\ State Epidemiologist, State Surveillance Unit, State Health Society, Bihar, ${ }^{(2)}$ Asst. Prof. Dept. of Dentistry, IGIMS, \\ Patna.
}

\section{Manuscript Info}

Manuscript History

Received: 09 January 2018

Final Accepted: 11 February 2018

Published: March 2018

Keywords:-

Acute Encephalitis Syndrome, Japanese Encephalitis, Per Man Hour Density,

\begin{abstract}
Acute Encephalitis Syndrome (AES) and Japanese Encephalitis (JE) is a major public health problem in Bihar leading to large scale morbidity and mortality especially among the childrens. Recurrent outbreaks of AES/JE have been reported in Muzaffarpur district, Bihar in recent years. Outbreak of AES/JE in Muzaffarpur in 2016 was investigated. Epidemiological, Entomological and Environmental investigations were carried out. From 5 Jan 2016 till 14 July 2016, total 70 cases and 7 deaths due to AES were reported in Muzaffarpur district. Out of the total reported cases, etiological confirmation could be done in $24 \%$ of the cases while etiology could not be confirmed in $76 \%$ of the cases. Out of the total confirmed cases, JE contributed $81 \%$ of the cases while the rest were confirmed as pyogenic and tubercular meningitis. Block Mushahri was the most affected followed by block Minapur. Fever, altered sensorium \& seizures were present in $100 \%$ of the cases. Outbreak peak was observed on 1-10 June 2016. Per Man Hour Density (PMHD) of culex was higher when compared to other mosquito species. Culicine Larval density/dip was higher in cattle feeding containers. Most of the affected population belonged to low socioeconomic strata. Awareness regarding the disease was also very less in the affected population. The study would help to identify the factors leading to the recurrent outbreaks in the region and for undertaking appropriate remedial actions.

Copy Right, IJAR, 2018,. All rights reserved.
\end{abstract}

\section{Introduction:-}

Japanese Encephalitis (JE) is caused by a virus which is transmitted through the bite of infected mosquitoes (Culex tritaeniorhyncus \& Vishnui) [1] and is one of the common cause of AES [2]. The main reservoirs of the JE virus are pigs and water birds and in its natural cycle, virus is maintained through certain mosquito species in these animals. Man is accidental host \& does not play a role in JE transmission. Multiple factors like virus, bacteria, fungi, parasites and toxins may cause AES [3]. It is estimated that a population of 375 million are at a risk of acquiring AES in India [4]. Besides JE virus (JEV), other viruses that have resulted in high incidence of AES in India are Dengue virus, Entero-virus, Herpes Simplex Virus (HSV), Measles and Chandipura virus [5]. However, etiology of AES remains unknown in 68-75\% of patients [6]. As per WHO, AES is defined as acute onset of fever and a change in mental status including symptoms such as confusion, disorientation, or inability to talk and/or new onset of seizures excluding febrile convulsions in a person of any age at any time of year. 
The present study was done to review and assess the situation of AES/JE outbreak in Muzaffarpur, to determine the causes of current outbreak, to conduct an epidemiological and also entomological survey in some of the affected areas of Muzaffarpur, to assess the environmental and sociological factors contributing to the abundance of JE vector, to assess the current situation by district wise analysis of AES/JE outbreak and to recommend remedial measures to overcome the current outbreak and prevent occurrence of outbreaks in future.

\section{Methodology:-}

This was a record based study where daily reports on AES cases in prescribed format was reported from district surveillance unit comprising of Govt Medical College \& Hospitals to the State Surveillance Unit. Lab reports for JE IgM ELISA, Pyogenic Meningitis and Tubercular Meningitis were also collected for recording respective cases. WHO case definition was used for inclusion of cases. Descriptive epidemiology based on time, place and person was used to analyze the outbreak trend of AES. Entomological investigations consisted of adult and larval survey as per standard protocol. Water logged places and containers were searched for the presence of culex larvae in the affected villages. Larvae were collected with the help of dippers. Three dips per sq $\mathrm{m}$ of breeding habitat surface area were taken. Adults were collected by 2 methods viz: Oral Aspirator and torch method by which Per Man Hour Density (PMHD) was calculated both indoors and outdoors. Total catch of mosquitoes was also done to determine species composition and its vectorial capability. The samples were sent to NIMR Ranchi for this purpose. Environmental investigations were done as per pre-planned questionnaire. Discussion was held with the District authorities and medical and paramedical staff to know the background information of the affected areas, genesis of outbreak, investigations carried out so far and control measures undertaken. Discussion was held with the physicians who treated the cases about the clinical presentation of cases, results of laboratory investigations and outcome of cases. Interview and clinical examination of some of the cases were done. Visit to the affected areas for rapid fever survey by house to house visit and collection of sera samples from suspected cases for JE confirmatory test was done.

\section{Site description/Muzaffarpur district profile:-}

Muzaffarpur district of Bihar is spread over an area of 3172 sq. kms. The district is bounded on the north by East Champaran and Sitamarhi districts, on the south by the district of Vaishali, on the east by the districts of Darbhanga and Samastipur (part) and on the west by Saran and part of Gopalganj districts. Important rivers include Bagmati, Gandak, Burhi Gandak \& Lakhandeye. Average rainfall is $1187 \mathrm{~cm}$ annually. The district has a population of 3.743 million (2001 census). Rural population in the district is $90.7 \%$ and urban population is $9.3 \%$. The density of the population was 929 per sq. kms. Literacy rate is 95\%. There are 2 Sub divisions, 16 Blocks, 387 Panchayats and 1811 villages. Agriculture is the main occupation in the district.

\section{Results and Discussion:- General Observations:-}

The team visited affected areas in village Bahbal Bazar (Minapur block), Jhapahan (Mushahari block) \& Salempur (Minapur block) for detailed outbreak investigation. Water logged places and containers were searched for the presence of culex larvae in the affected villages. Most of the affected areas visited, were comprised of agricultural labour population. Agriculture and Live stock rearing including Piggery was a major source of livelihood in the affected areas that were visited. The JE cases that were met had been previously vaccinated. As per information from the villagers, the Pig farms were located within $1 \mathrm{Km}$ of the residence of the affected JE cases. This is an important finding as the presence of culex mosquitoes in the affected areas and its flight range of 1-2 kms from the pig dwellings might have led to JE transmission. Majority of the population were illiterate and belonged to lower socio-economic strata.

\section{Epidemiological results:-}

Overall 70 cases of AES were reported in Muzaffarpur till 16 July 2016. Out of 70 cases, 13 cases were confirmed to be Japanese Encephalitis while other 2 as pyogenic and tubercular meningitis. Most affected block was Mushahri (14 cases)>Minapur (10 cases).Approximately in all the cases, most common symptoms were fever, altered sensorium and seizures. Age group most affected was 0-4 (52\%)>5-9 (41\%). Males (54\%) were more affected than females (46\%). Outbreak peak laid from 1-10 June 16 when 27 cases and 2 deaths were reported. Out of the two fever samples tested for JE by State IDSP team in PMCH, Patna one sample was negative while other was equivocal with strong inclination towards positivity. 
Fig 1:- Descriptive Epidemiological Analysis of AES/JE outbreak in Bihar

\begin{tabular}{|c|c|c|c|c|c|c|}
\hline \multicolumn{7}{|c|}{ Comparison of AES/JE outbreak in $2011,2012,2013,20148,2015$} \\
\hline $\begin{array}{l}51 \\
\text { No }\end{array}$ & $\begin{array}{c}\text { Epidemiological } \\
\text { Indices }\end{array}$ & 2011 & 2012 & 2013 & 2014 & 2015 \\
\hline \multirow{4}{*}{ 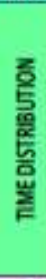 } & $\begin{array}{c}\text { Date of start of } \\
\text { outbreak }\end{array}$ & 23-Jul & 16-May & G-Apr & 31-May & 9-Mar \\
\hline & Outbreak peak & $\begin{array}{l}21 \text { sep to } 25 \\
\text { Oct (s23 } \\
\text { cases) }\end{array}$ & $\begin{array}{l}5 \text { Jun to } 27 \text { Jun } \\
\text { ( } 555 \text { cases) }\end{array}$ & $\begin{array}{l}5 \text { Jun to } 14 \text { Jun }(90 \\
\text { cases) }\end{array}$ & $\begin{array}{l}10 \text { Jun to } 19 \text { Jun } \\
15 \text { ( } 342 \text { cases) }\end{array}$ & $\begin{array}{c}7 \text { Jun to } 16 \text { Jun } \\
15825 \operatorname{sep}^{-4} \\
\text { Oct-15 }\end{array}$ \\
\hline & $\begin{array}{l}\text { Date from which } \\
\text { outbreak peak declined } \\
\text { rapidiy }\end{array}$ & $14-\mathrm{Nov}$ & 16-NoY & $12-\operatorname{sep}$ & 1-Jul & T-Jul 8 24-Nov \\
\hline & Date of end of outbreak & 4th Dec & 31-Dec & 21-Dec & 31 -Dec & 4-Dec \\
\hline 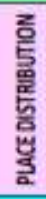 & $\begin{array}{l}\text { District with maximum } \\
\text { incidence of AES/JE }\end{array}$ & $\begin{array}{c}\text { Gava (298 } \\
\text { case)>Patna } \\
\text { (114 } \\
\text { case) }>\text { Auran } \\
\text { eabad (65 } \\
\text { case)>saran } \\
\text { (61 case) }\end{array}$ & $\begin{array}{c}\text { Muzaffarpur ( } 934 \\
\text { cases) }>\text { Patna (182 } \\
\text { case) }>E \\
\text { Champaran } \\
=\text { sitamarhi ( } 58 \\
\text { case) }>\text { Vaishall ( } 57 \\
\text { case) }>\text { Gava }(44 \\
\text { case) }\end{array}$ & $\begin{array}{c}\text { Muzatfarpur (135 } \\
\text { case) }>\text { Patna ( } 53 \\
\text { case) }>\text { E Champaran } \\
\text { (32 } \\
\text { case) }>\text { sitamarhi } \\
\text { (20 case) }\end{array}$ & $\begin{array}{c}\text { Muzaffarpur } \\
\text { (358 case)>E } \\
\text { Champaran(130 } \\
\text { case) } \times \text { Patna } \\
\text { (90)> Gava (67) }\end{array}$ & $\begin{array}{c}\text { Muzaffarpur } \\
\text { ( } 81 \\
\text { cases) } \\
\text { (76 cases) }>E \\
\text { Champaran ( } 33 \\
\text { cases) }\end{array}$ \\
\hline \multirow{7}{*}{$\begin{array}{l}\frac{2}{5} \\
\frac{1}{5} \\
\frac{5}{5} \\
\frac{8}{8} \\
\frac{2}{2}\end{array}$} & $\begin{array}{l}\text { Total cases reported } \\
\text { due to AES }\end{array}$ & 941 & 1095 & 450 & 1005 & 390 \\
\hline & $\begin{array}{c}\text { Total deaths reported } \\
\text { due to AES }\end{array}$ & 187 & 395 & 159 & 372 & 100 \\
\hline & Case Fatality Rate/100 & 20 & 36 & 35.33 & 36.47 & 25.64 \\
\hline & $\begin{array}{l}\text { Total JE positive cases } \\
\text { durine the autbreak: }\end{array}$ & 181 & 18 & 30 & 23 & 78 \\
\hline & $\begin{array}{l}\text { Total if positive deaths } \\
\text { durine the outbreak. }\end{array}$ & 21 & 0 & 0 & 0 & 19 \\
\hline & $\begin{array}{c}\text { Age group most } \\
\text { affected }\end{array}$ & $\begin{array}{c}5-9(395 \\
\text { case })>10-14 \\
(277 \\
\text { case })>0-4 \\
(241 \text { case })\end{array}$ & $\begin{array}{c}0-4(561 \text { case })>5-9 \\
(374 \text { case })>10-14 \\
(132 \text { case })\end{array}$ & $\begin{array}{c}0-4(222 \text { case })>5-9 \\
(142 \text { case })>10-14 \\
(64 \text { case })\end{array}$ & $\begin{array}{c}0.4(546 \\
\text { case) }>5.9(364 \\
\text { case) }>10-14 \\
(112 \text { case) }\end{array}$ & $\begin{array}{c}0-4(181 \\
\text { case })>5-9(132 \\
\text { case })>-10-14 \\
\text { (56 case) }\end{array}$ \\
\hline & Sex most affected & $\begin{array}{c}\text { Male (5so } \\
\text { cases) }>\text { Fem } \\
\text { ale ( } 411 \\
\text { case) }\end{array}$ & $\begin{array}{c}\text { Female }(603 \\
\text { case })>\text { Male }(491 \\
\text { case) }\end{array}$ & $\begin{array}{c}\text { Male }(255 \\
\text { case) }>\text { Female (185 } \\
\text { Cases) }\end{array}$ & $\begin{array}{l}\text { Male ( } 570 \\
\text { case) }>\text { Femal } \\
\text { e ( } 458 \text { case) }\end{array}$ & $\begin{array}{c}\text { Male } \\
(231)>\text { Ferna } \\
\text { le }(159)\end{array}$ \\
\hline
\end{tabular}

Fig 2:- Date wise AES/JE outbreak situation Muzaffarpur in 2016

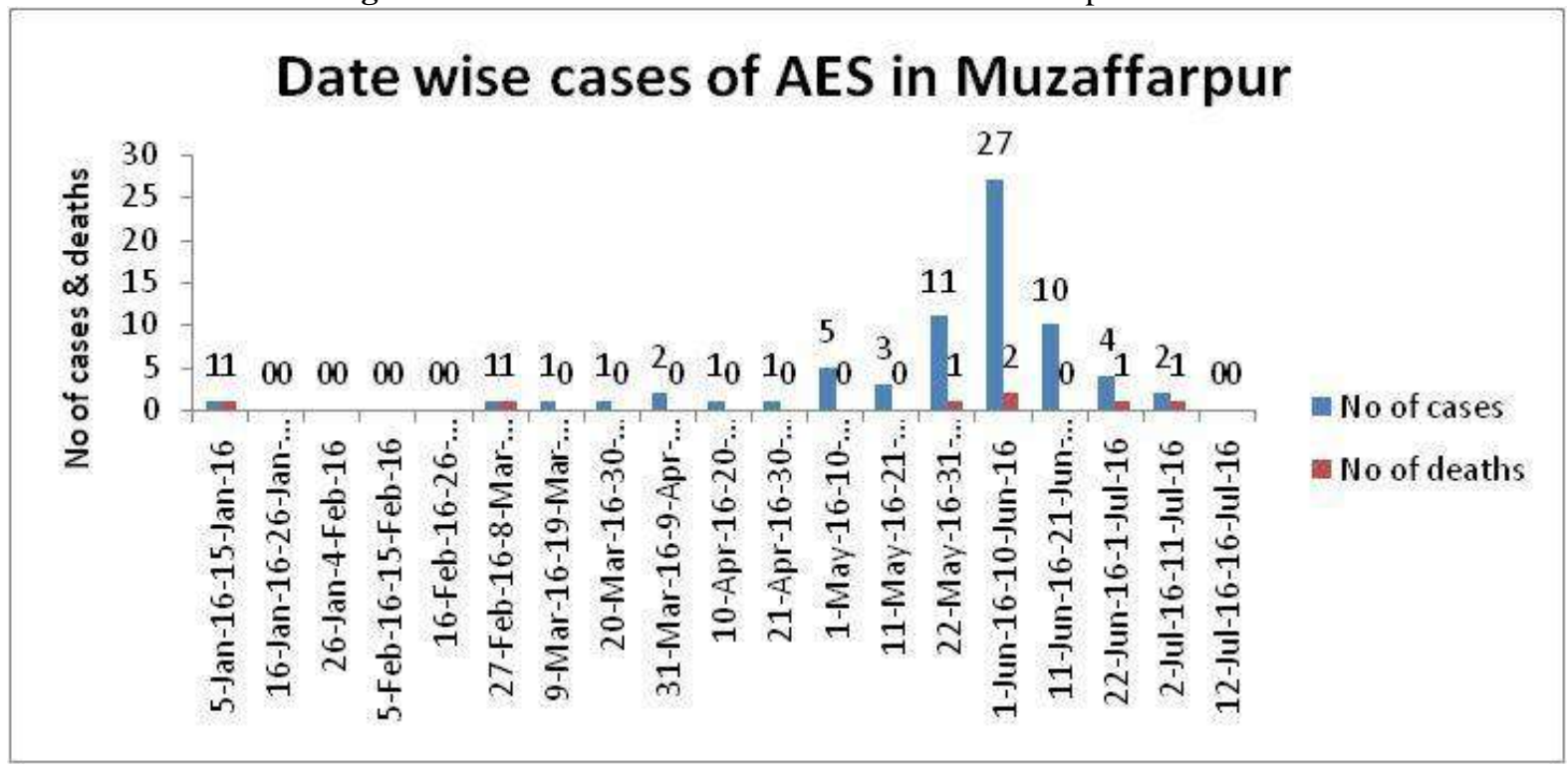


Fig 3:- Place wise distribution of AES/JE in Muzaffarpur

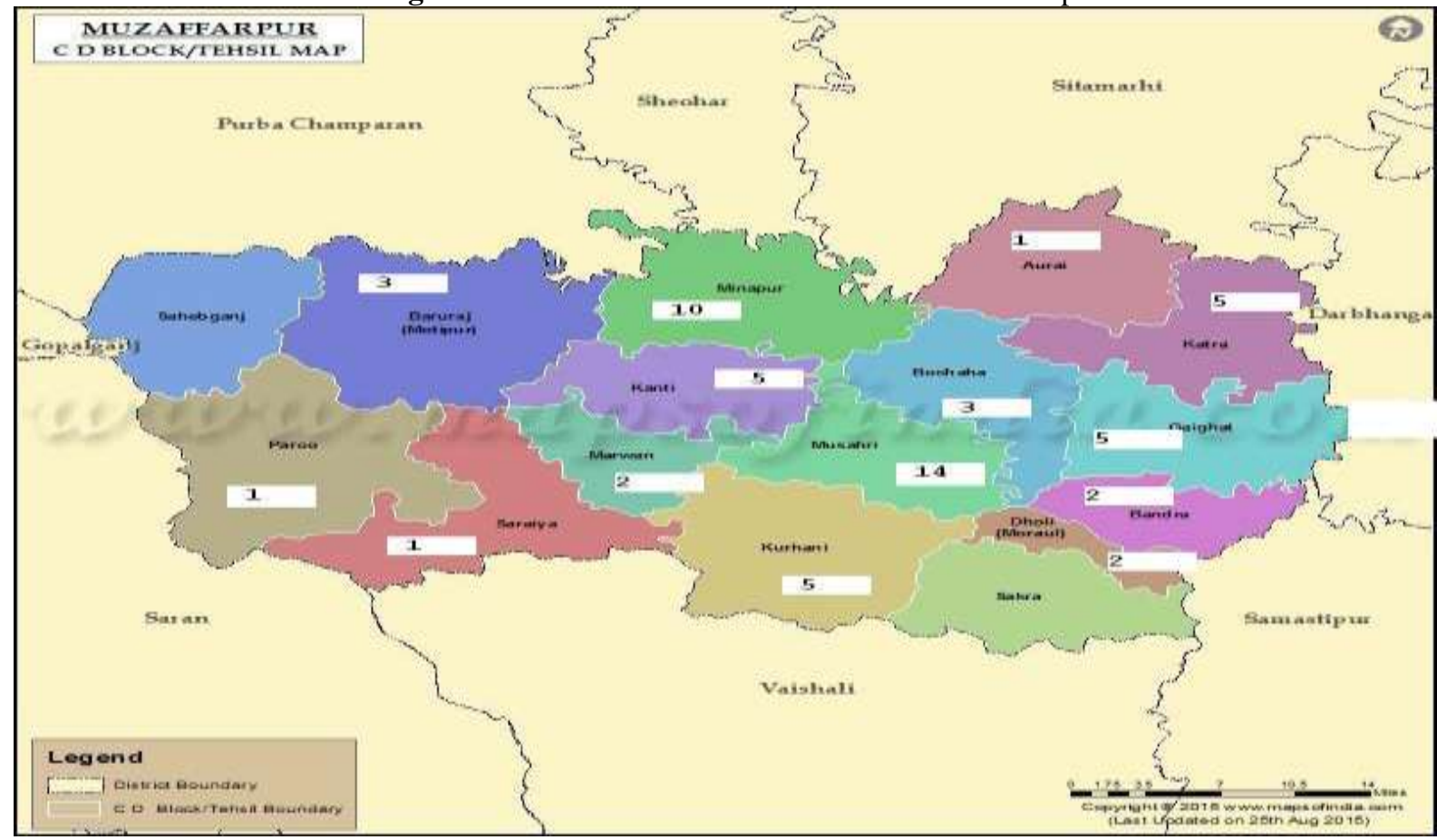

Table 1:- Person wise distribution of AES/JE in Muzaffarpur

\begin{tabular}{|c|c|c|}
\hline Age Group & Frequency & Percentage (\%) \\
\hline $0-4$ & 36 & 52 \\
\hline $5-9$ & 29 & 41 \\
\hline $10-14$ & 5 & 7 \\
\hline $15 \& 15+$ & 0 & 0 \\
\hline Total & $\mathbf{7 0}$ & $\mathbf{1 0 0}$ \\
\hline Sex & Frequency & Percentage (\%) \\
\hline Male & 38 & 46 \\
\hline Female & 32 & $\mathbf{1 0 0}$ \\
\hline Total & $\mathbf{1 0 0}$ & 46 \\
\hline
\end{tabular}

Table 2:- Institution wise Status of AES/JE in Muzaffarpur

\begin{tabular}{|c|c|c|}
\hline \multicolumn{2}{|c|}{ Institutional Status of AES cases in Muzaffarpur } \\
\hline Sl.No. & Parameters & Status \\
\hline 1 & Total AES cases till 16 Jul 16 & 70 \\
\hline a & Discharged & 60 \\
\hline b & Death & 7 \\
\hline c & Admit & 0 \\
\hline d & LAMA & 3 \\
\hline 2 & Total AES Unknown & 53 \\
\hline 3 & Total AES confirmed & 16 \\
\hline a & JE +ve case/death & $13 / 1$ \\
\hline 4 & No of Blocks affected & 16 \\
\hline 5 & Most affected blocks & Mushahri (14)>Minapur (10) \\
\hline
\end{tabular}

Table 3:- Clinical Profile of AES/JE cases ( $n=15)$

\begin{tabular}{|c|c|c|}
\hline \multicolumn{3}{|c|}{ Clinical profile of AES/JE cases (n=15) } \\
\hline Fever & 15 & $100 \%$ \\
\hline Altered Sensorium & 15 & $100 \%$ \\
\hline
\end{tabular}




\begin{tabular}{|c|c|c|}
\hline Vomiting & 8 & $0.01 \%$ \\
\hline Headache & 5 & $33 \%$ \\
\hline Seizures & 15 & $100 \%$ \\
\hline
\end{tabular}

\section{Entomological results:-}

Two species of mosquitoes were collected and identified from above indoor habitats during dusk hours which were as under: Culex: 79; Anopheles: 29. Overall Per Man Hour density in order of prevalence are: Culex>Anopheles. Maximum number of collection for Culex was made from Cattle shed while for Anopheles it was from Human Dwellings. For larval survey, collection from breeding areas like Paddy field, cattle feeding containers, other water containers \& pots were searched. Anopheline and Culicine larvae could be identified. Density per dip was maximum in cattle feeding containers

Table 4 A:- Per Man Hour Density of Mosquitoes in Village Bhabal Bazar, Jhapahan \& Salempur

\begin{tabular}{|c|c|c|c|c|c|}
\hline \multicolumn{6}{|c|}{ Per man hour density } \\
\hline \multicolumn{6}{|c|}{ Block Minapur, Village Bhabal Bazar } \\
\hline \multirow[t]{2}{*}{ Mosquito species } & \multicolumn{4}{|c|}{ Indoor } & Outdoor \\
\hline & HD & CS & MD & PMHD & $\begin{array}{c}\text { PMHD (Plantations, Bushes } \\
\text { etc) }\end{array}$ \\
\hline Culex & 6 & 12 & 9 & 0.6 & 0.4 \\
\hline Anopheles & 3 & 4 & 3 & 0.22 & 0.2 \\
\hline Aedes & $\mathbf{0}$ & $\mathbf{0}$ & $\mathbf{0}$ & $\mathbf{0}$ & $\mathbf{0}$ \\
\hline \multicolumn{6}{|c|}{ Per man hour density } \\
\hline \multicolumn{6}{|c|}{ Block Mushahri, Village Jhapahan } \\
\hline \multirow[t]{2}{*}{ Mosquito species } & \multicolumn{4}{|c|}{ Indoor } & Outdoor \\
\hline & HD & CS & MD & PMHD & $\begin{array}{c}\text { PMHD (Plantations, Bushes } \\
\text { etc) }\end{array}$ \\
\hline Culex & 7 & 13 & 16 & 0.8 & 0.6 \\
\hline Anopheles & 2 & 4 & 6 & 0.26 & 0.1 \\
\hline Aedes & $\mathbf{0}$ & $\mathbf{0}$ & $\mathbf{0}$ & $\mathbf{0}$ & $\mathbf{0}$ \\
\hline \multicolumn{6}{|c|}{ Per man hour density } \\
\hline \multicolumn{6}{|c|}{ Block Kanti, Village Salempur } \\
\hline \multirow[t]{2}{*}{ Mosquito species } & \multicolumn{4}{|c|}{ Indoor } & Outdoor \\
\hline & HD & $\mathbf{C S}$ & MD & PMHD & $\begin{array}{c}\text { PMHD (Plantations, Bushes } \\
\text { etc) }\end{array}$ \\
\hline Culex & 4 & 10 & 6 & 0.4 & 0.2 \\
\hline Anopheles & 1 & 1 & 5 & 0.1 & 0.1 \\
\hline Aedes & $\mathbf{0}$ & $\mathbf{0}$ & $\mathbf{0}$ & $\mathbf{0}$ & $\mathbf{0}$ \\
\hline
\end{tabular}

$\mathrm{T}=45 \mathrm{~min}$

Table 4 B:- Details of Mosquito breeding Sites in village Bhabal Bazar, Jhapahan \& Salempur (combined)

\begin{tabular}{|l|c|c|c|c|}
\hline \multicolumn{1}{|c|}{$\begin{array}{c}\text { Details of Mosquito } \\
\text { Breeding sites }\end{array}$} & No. Checked & $\begin{array}{c}\text { No. found } \\
\text { positive }\end{array}$ & $\begin{array}{c}\text { Avg Density/Dip(3 dips } \\
\text { done) }\end{array}$ & $\begin{array}{c}\text { Name of the } \\
\text { species identified }\end{array}$ \\
\hline Paddy field & 4 & 1 & 6 & Culex \\
\hline Cattle feeding containers & 5 & 3 & 12 & Anopheles \\
\hline $\begin{array}{l}\text { Household water } \\
\text { containers }\end{array}$ & 10 & 4 & 6 & Anopheles \\
\hline Pots/vases & 5 & 0 & 0 & \\
\hline Coconut/Palm Shells & 0 & 0 & 0 & \\
\hline
\end{tabular}

Environmental \& Sociological Observations and Results:-

Most of the affected population belonged to low socio-economic strata, with most of the houses being semi pucca/Kutcha category. Sanitation and hygiene in affected areas were also poor. Majority of them were illiterate and 
unaware of the cause of the disease. Awareness regarding disease control \& prevention was also very less. Piggeries were found within $1 \mathrm{Km}$ range of the JE affected cases.

Table 5:- Socio-demographic Profile of respondents

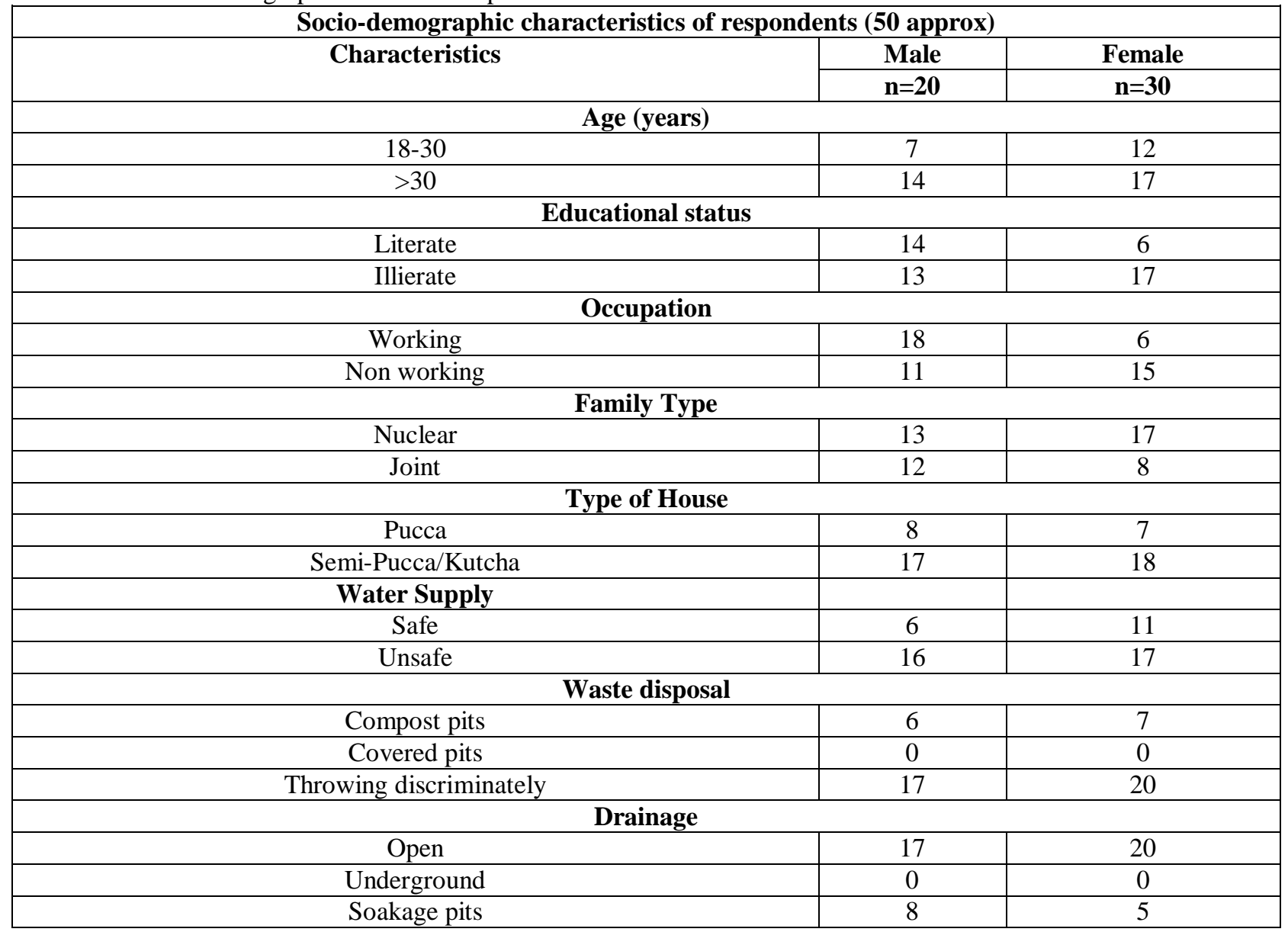

Table 6:- Awareness \& knowledge regarding selected mosquito-borne diseases

\begin{tabular}{|c|c|}
\hline Characteristics & No. of respondents $(\mathrm{n}=50$ approx $)$ \\
\hline \multicolumn{2}{|c|}{ Sources of information } \\
\hline TV & 19 \\
\hline Radio & 14 \\
\hline Newspapers & 2 \\
\hline Health Care Providers & 10 \\
\hline Others & 5 \\
\hline \multicolumn{2}{|c|}{ Serious problem in area } \\
\hline Yes & 40 \\
\hline No & 10 \\
\hline \multicolumn{2}{|c|}{ Breeding places } \\
\hline Ditches & 18 \\
\hline Ponds & 3 \\
\hline Vehicle tyres & 0 \\
\hline Stagnant Water & 20 \\
\hline Coconut shells & 0 \\
\hline Others & 9 \\
\hline \multicolumn{2}{|c|}{ Causative agents } \\
\hline Mosquito bite & 12 \\
\hline
\end{tabular}




\begin{tabular}{|c|c|}
\hline Drinking dirty water & 8 \\
\hline Overwork/sun exposure & 6 \\
\hline Food & 0 \\
\hline Others & 7 \\
\hline Don't know Disease transmitted by mosquitoes \\
\hline Malaria & 15 \\
\hline Dengue & 24 \\
\hline Chikungunya & 12 \\
\hline Filaria & 1 \\
\hline Others & 2 \\
\hline Don't know & 4 \\
\hline Environmental & 7 \\
\hline Chemical & 12 \\
\hline Biological & 28 \\
\hline Integrated & 3 \\
\hline Don't know & 0 \\
\hline
\end{tabular}



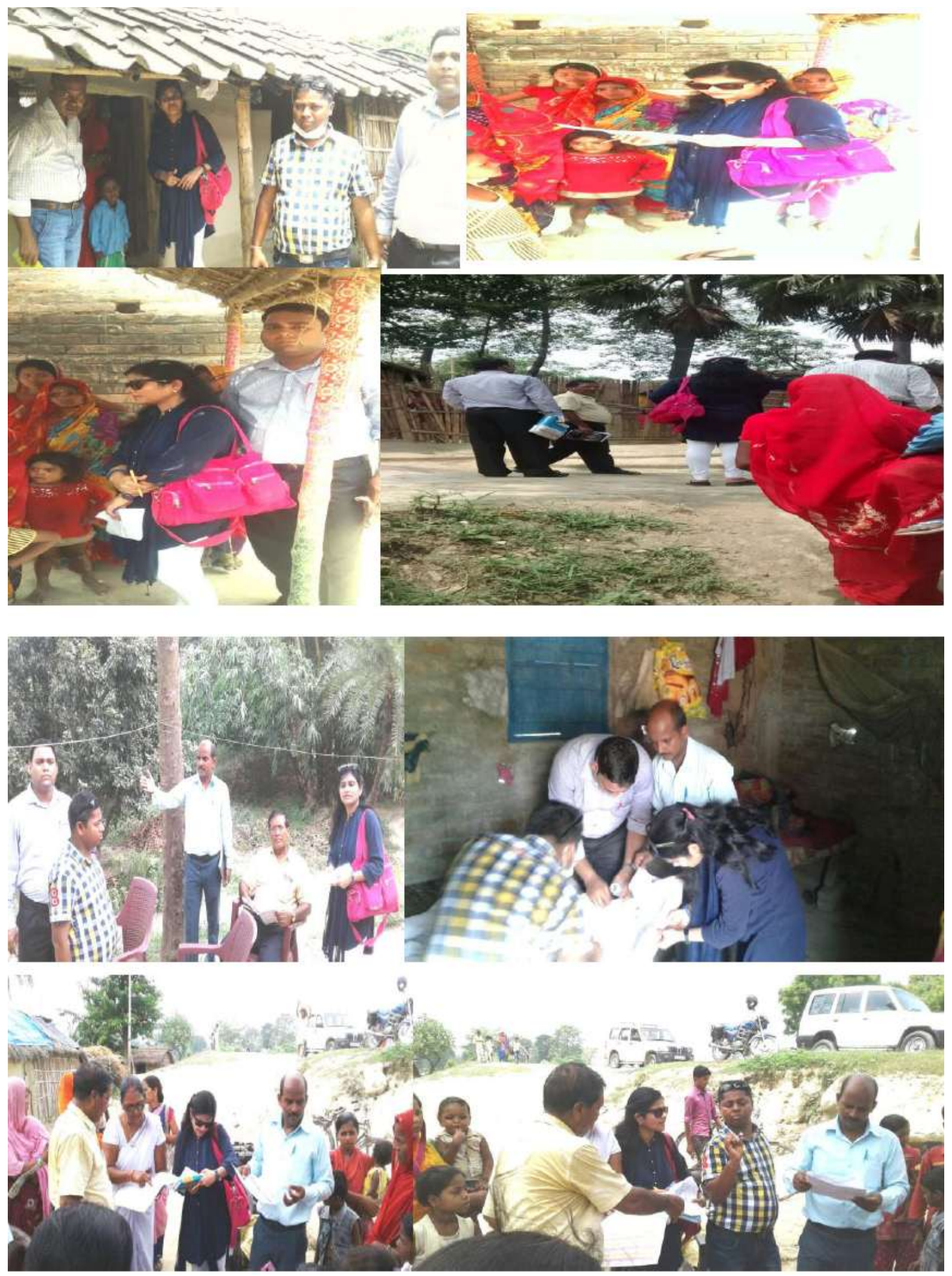

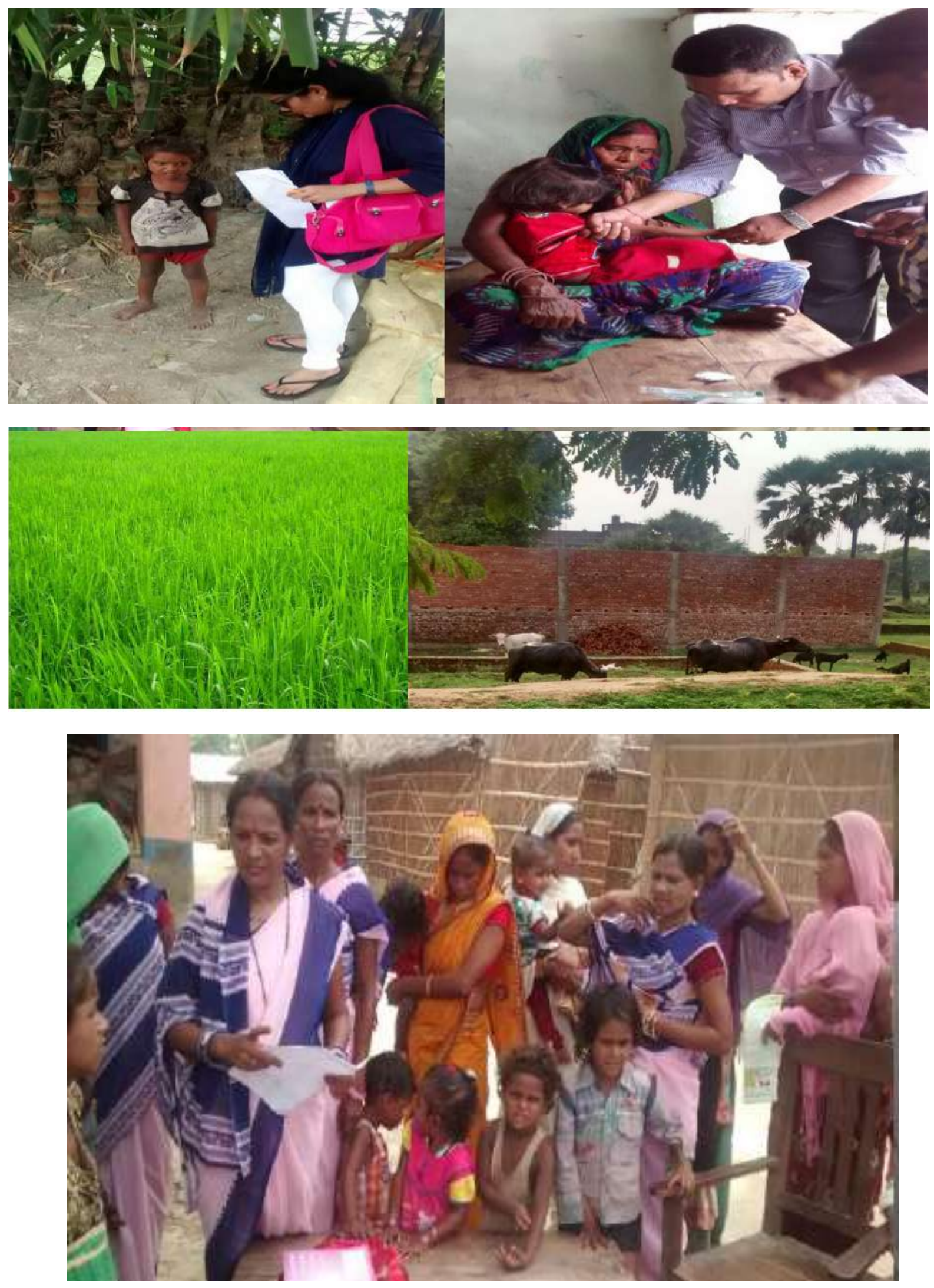


\section{Conclusion:-}

Overall, 70 cases \& 7 deaths were reported due to AES/JE in Muzaffarpur from 5 Jan 16 till 16 July 2016. Case Fatality Rate/100 due to the disease was 0.1 .Out of 70 AES cases, 13 cases \& 1 death were confirmed as JE, 3 others as Pyogenic and Tubercular Meningitis while remaining cases remained undiagnosed. Age group most affected was 0-4>5-9. Males were more affected than females. Majority of the JE cases were previously immunized and had completely recovered with no neurological deficits. Mushahri block was most affected >Minapur block. Entomological investigations revealed that PMHD of Culex was higher when compared to Anopheles favouring transmission of JE. Most common breeding sites for larvae were cattle feeding containers>household containers. As per informants of the affected areas, only focal spray/fogging was done in affected area once. Amplifying hosts, pigs were present near the JE affected areas. Most of the affected population belonged to low socio-economic strata, with most of the houses being semi-pucca/kutcha category. Sanitation and hygiene in affected areas were also poor. Majority of them were illiterate and unaware of the cause of the disease. Awareness regarding disease control $\&$ prevention was also very less. With the advent of monsoon season, water logging in various places including paddy field may further aggravate JE transmission if appropriate steps are not taken on regular basis. There is urgent need for fogging in JE affected areas at regular intervals. Intensive IEC activities and awareness creation among community through Health Workers should also be undertaken along with enhancing fever surveillance and it's reporting on daily basis for early identification of suspected cases for prompt treatment and control.

\section{Recommendations:-}

1. Adequate and timely availability of medicines, kits, logistics, equipments etc.

2. Enhancing fever surveillance and it's reporting through Health Workers on daily basis for early identification of suspected cases for prompt treatment and control

3. Daily reporting of suspected cases should be shared with the State by the MCH.

4. Measures for source reduction should be immediately implemented. Use of kerosene, diesel oil in water logged places on weekly basis by community participation should be undertaken. Alternatively, spray of larvicide may be undertaken for source reduction.

5. District RRT should be activated for investigation \& containment of the outbreak. This should include the Animal Husbandry Department as well. Awareness on covering the pigs sheds residing along with human population with mosquito/mesh nets may be undertaken by Animal Husbandry Department in coordination with Health Department.

6. PHCs should also be made well equipped to manage any outbreak. For this Technical Malathion, fogging machines, health education materials, preliminary lab investigation and transportation of cases to referral Centres should be made available before the transmission season.

7. Vector \& larval surveillance should be carried out throughout the year to map the vector density \& larval breeding sites. For this VBD consultants/KTS should be made well equipped and trained.

8. Case management through early diagnosis \& prompt treatment must be done. Camp based approach for active case search of AES/JE must be undertaken.

9. JE Vaccination of susceptible population should be carried out on urgent basis.

10. Awareness of Community through IEC, IPC \& BCC must be done for success of intervention methods.

11. All districts adjoining the districts where a case of JE/AES has been recorded should be made alert \& an eye on all the AES cases should be kept for timely referral \& cases management.

\section{Conflict of interest:-}

There is no conflict of interest among the authors. 


\section{References:-}

1. Self, L.S., H.K. Shin, K.H. Kim, K.W. Lee, C.Y. Chow H.K. Hong, 1973. Ecological studies on Culex tritaeniorhynchus as a vector of Japanese encephalitis, Bull World Health Organ. 49(1): 41-47.

2. $\mathrm{NB}_{1}, \mathrm{DM}$ and $\mathrm{RM}, \mathrm{NB}_{2}$ conceptualized the study, participated in the design of microbiological and epidemiological portion, facilitated the overall study activities and revised the manuscript critically

3. Jmor F, Emsley HCA, Fischer M, etal. The incidence of acute encephalitis syndrome in Western industrializes and tropical countries. Virol J. 2008; 5:134

4. Potharaju NR. Incidence rate of AES without specific treatment in India and Nepal. Indian J Comm Med, 2012, 37:240-251

5. Saxena SK, Mishra N, Saxena R, etal. Trend of Japanese Encephalitis in North India:evidence from 38 AES patients and approval of niceties. J Infect Dev Ctries, 2009; 30:517-530

6. Kennedy PG. Viral encephalitis: causes, differential diagnosis \& management. J. Neurol Neurosurgery Psychiatry. 2004; 75:10-15 